\title{
PENGARUH KONTROL DIRI DAN KECEMASAN TERHADAP PROKRASTINASI PECINTA ALAM UIN SYARIF HIDAYATULLAH JAKARTA
}

\author{
Rahajeng Mustikaningsih, Gazi Saloom, dan Nia Tresniasari \\ UIN Syarif Hidayatullah Jakarta \\ nia.tresniasari@uinjkt.ac.id
}

\begin{abstract}
This reasearch was done in order to know influence of self control toward anxiety of academic procrastination among students joining in organizations of natural lovers. It used quantitative method by distributing scales of self control and anxiety of academic procrastination to students who have been chosen as samples. The result of reaserch showed that self control has big impact toward anxiety of academic procrastination among students. This research supported previous reasearches about anxiety of academic procrastination. Suggestions related to the result's research was discussed.
\end{abstract}

Keywords: Self-Control, Anxiety, Academic Procrastination

\begin{abstract}
Abstrak
Penelitian ini dilakukan untuk mengetahui pengaruh kontrol diri terhadap kecemasan prokrastinasi akademik mahasiswa yang tergabung di dalam organisasi pecinta alam. Penelitian ini menggunakan metode kuantitatif dengan mendistribusikan skala kontrol diri dan kecemasan prokrastinasi akademik kepada mahasiswa sebagai sampelnya. Hasil dari penelitian ini menunjukkan bahwa kontrol diri memiliki pengaruh yang besar terhadap kecemasan akademik prokrastinasi mahasiswa. Penelitian ini mendukung penelitian sebelumnya mengenai kecemasan akademik prokrastinasi. Saran yang beruhubungan dengan hasil penelitian didiskusikan.
\end{abstract}

Kata Kunci: Kontrol Diri, Kecemasan, Prokrastinasi Akademik

Diterima: 30 Oktober 2012 Direvisi: 28 November 2012 Disetujui: 6 Desember 2012 


\section{PENDAHULUAN}

Di negara-negara maju secara umum penduduknya sudah memiliki kesadaran tinggi akan arti penting pendidikan dan penguasaan iptek. Hal tersebut terlihat dari angka partisipasi belajar penduduk negara-negara maju yang sangat tinggi. Partisipasi belajar yang tinggi menuntut seseorang untuk mempunyai sikap disiplin yang tinggi pula. Sikap disiplin merupakan sikap yang harus ditingkatkan, karena memberi manfaat dan sumbangan yang besar untuk menjadikan seseorang yang berkualitas.

Berhubungan dengan mansusia yang berkualitas, dalam khasanah ilmu psikologi terdapat istilah prokrastinasi yang menunjukkan suatu sikap yang tidak disiplin dalam penggunaan waktu. Dalam Cho \& Chu (2005) banyak orang mengklaim bahwa ketika mereka mulai bekerja pada menitmenit terakhir, mereka masih bisa selesai tepat waktu dan mereka cenderung bekerja lebih baik dan lebih cepat atau menghasilkan lebih banyak ide kreatif di bawah tekanan waktu.

Hasil penelitian Solomon \& Rothblum (1984) pada mahasiswa Universitas Vermont menunjukkan bahwa data frekuensi penundaan untuk berbagai tugas akademis $46 \%$ dari subyek melaporkan bahwa mereka hampir selalu atau selalu menunda-nunda untuk mempelajari makalah, $27,6 \%$ menunda-nunda belajar untuk ujian, dan 30,1\% menunda-nunda untuk membaca tugas mingguan, menunda-nunda pada untuk mengerjakan tugas-tugas administratif (10,6\%), tugas pertemuan (23\%), dan kegiatan sekolah pada umumnya $(10,2 \%)$.

Hal ini didukung oleh survei yang dilakukan peneliti pada salah satu organisasi pecinta alam pada tahun 2012 yang menemukan bahwa dari 21 mahasiswa, $70 \%$ diantaranya lulus tidak tepat waktu. Selain itu, pada 74 mahasiswa yang masih aktif dalam perkuliahan, $80 \%$ diantaranya mengulang beberapa mata kuliah. Hal tersebut yang akhirnya memunculkan paradigma bagi beberapa orang bahwa Mahasiswa Pecinta Alam "MAPALA" adalah mahasiswa yang paling lama dikarenakan kebanyakan mahasiswa yang tergabung dalam organisasi pecinta alam menyelesaikan studinya tidak tepat waktu.

Terdapat beberapa faktor yang mempengaruhi prokrastinasi akademik pada mahasiswa, namun peneliti hanya mengambil 2 faktor yang mempengaruhi hal tersebut, yakni kontrol diri dan kecemasan, dan ditambah dengan 2 faktor demografis, yakni usia dan jenis kelamin.

Penelitian yang dilakukan oleh Kuhnle, Manfred, \& Britta (2011) menyatakan bahwa kontrol diri telah terbukti menjadi prediktor yang baik dari prokrastinasi. Individu jelas menunda-nunda karena mereka tidak bisa mengendalikan perilaku mereka dan lebih memilih untuk mengikuti kegiatan jangka pendek yang menyenangkan daripada berpegang pada tujuan mereka. Hal ini didukung oleh hasil penelitian Ghufron (2004) yang 
menemukan bahwa semakin rendah kontrol diri semakin tinggi prokrastinasi akademik pada remaja, begitu pula sebaliknya, semakin tinggi kontrol diri, maka semakin rendah prokrastinasi akademik terbukti.

Selain faktor kontrol diri, peneliti juga melihat faktor kecemasan juga mempengaruhi prokrastinasi akademik. Hal ini didukung oleh penelitian Haycock (1998) yang menyatakan bahwa kecemasan merupakan variabel lain yang sering diteliti, baik dalam penelitian tentang prokrastinasi maupun dalam penelitian tentang self efficacy. Selain itu, Sharma (1997) menemukan bahwa kecemasan merupakan salah satu faktor yang berhubungan dengan prokrastinasi.

Sampai saat ini, variabel demografi yang konsisten diteliti dalam studi prokrastinasi adalah jenis kelamin dan usia. Beberapa penelitian menunjukkan tidak ada perbedaan jenis kelamin yang signifikan dalam terjadinya prokrastinasi, sedangkan penelitian lain menunjukkan bahwa wanita berada pada resiko yang lebih besar daripada laki-laki. Selain itu, wanita mungkin mengalami tingkat kecemasan yang lebih besar terkait dengan prokrastinasi (Haycock, 1998).

Steel (2007) menyatakan bahwa faktor usia juga menjadi faktor untuk mengembangkan informasi tentang subjek penelitian. Hal ini juga diperkuat oleh penelitian Haycock (1998) yang juga memasukkan faktor usia menjadi variabel yang ikut diteliti untuk melihat apakah faktor usia juga menjadi faktor yang mempengaruhi prokrastinasi.

Peneliti tertarik untuk melakukan penelitian dengan mahasiswa yang tergabung dalam organisasi pecinta alam sebagi subjek penelitian. Mahasiswa yang tergabung dalm organisasi pecinta alam seharusnya terlatih untuk mempunyai kontrol diri yang baik, karena saat mereka berada pada situasi alam yang tidak menentu, mereka harus dapat berpikir dan bertindak untuk dapat keluar dari situasi yang mengancam. Saat itulah tingkat kecemasan mereka diuji. Saat mereka terlalu cemas dalam menghadapi semua keadaan yang tidak sesuai, bisa jadi merekalah yang akan menjadi "korban" dari alam yang mereka kunjungi.

Berdasarkan penjelasan diatas, meskipun sebelumnya telah dilakukan penelitian mengenai variabel kontrol diri dan kecemasan yang dikaitkan dengan prokrastinasi akademik, namun relevansi kekinian data tersebut masih perlu untuk diteliti kembali, apakah hasil tersebut masih relevan atau tidak jika menggunakan subjek yang berbeda dengan penelitian sebelumnya. Tujuan penelitian ini adalah untuk menguji pengaruh kontrol diri, kecemasan, jenis kelamin, dan usia terhadap prokrastinasi akademik pada mahasiswa anggota organsisasi pecinta alam yang terdapat di UIN Syarif Hidayatullah Jakarta.

\section{Prokrastinasi Akademik}

Prokrastinasi adalah perbuatan sia-sia dalam menunda tugas, tidak sematamata penelitian yang berhubungan dengan kebiasaan-kebiasaan atau 
manajemen waktu, tetapi juga melibatkan interaksi komplek dari komponen-komponen tingkah laku, kognitif, dan afektif (Solomon \& Rothblum, 1984).

Prokrastinasi telah dianggap sebagi perilaku yang membuang-buang waktu, kinerja yang buruk, dan stres yang meningkat. Banyak orang mengklaim bahwa ketika mereka mulai bekerja pada menit-menit terakhir, mereka masih bisa selesai tepat waktu dan mereka cenderung bekerja lebih baik dan lebih cepat atau menghasilkan lebih banyak ide kreatif di bawah tekanan waktu (Cho \& Chu, 2005).

Dari berbagai definisi yang dijabarkan oleh para ahli diatas, dapat diambil kesimpulan bahwa secara umum prokrastinasi merupakan tingkah laku seseorang untuk memulai atau menyelesaikan tugas secara keseluruhan karena adanya ketakutan untuk gagal dan pandangan bahwa segala sesuatu harus dilakukan dengan benar, yang mengakibatkan tugas-tugas menjadi terbengkalai, bahkan bila diselesaikan hasilnya menjadi tidak maksimal. Penundaan juga bisa mengakibatkan seseorang kehilangan kesempatan dan peluang yang datang.

Menurut Solomon \& Rothblum (1984) terdapat enam jenis tugas pada prokrastinasi akademik, yaitu (1) menulis (tugas mengarang); (2) belajar untuk menghadapi ujian; (3) membaca; (4) kinerja administratif; (5) menghadiri pertemuan; dan (6) kinerja akademik secara keseluruhan. Keenam jenis tugas ini dijadikan dasar untuk membuat alat ukur dalam penelitian ini.

Ada beberapa faktor yang mempengaruhi prokrastinasi akademik yang dikemukakan oleh beberapa ahli (Steel, 2007; Ghufron, 2004; Ariely \& Wertenbroch, 2002; Haycock, 2001) sebagai berikut:

1. Karakteristik tugas, dibagi menjadi 2, yaitu:

a. Waktu pemberian reward and punishment, Samuel Johnson dalam Piers (2007) berpendapat bahwa temporal proximity sebagai penyebab alami prokrastinasi. Prokrastinasi menurun ketika tugas semakin dekat (temporal proximity).

b. Taskaversiveness, maksudnya adalah mengacu pada tindakan yang tidak menyenangkan. Ketika sekali berusaha untuk menghindari stimulus yang aversive dan konsekuensinya semakin menjadi situasi aversive (tidak menyenangkan), semakin besar untuk menjauhi tugas.

2. Perbedaan individual

Percobaan untuk menentukan hubungan antara prokrastinasi dengan perbedaan individual sudah banyak. Para peneliti membagi perbedaan individual ke dalam lima tipe kepribadian.

3. Demografi

Munculnya perilaku prokrastinasi di populasi tidak hanya disebabkan oleh sifat-sifat kepribadian saja. Beruntungnya peneliti sudah secara konsiten memberikan informasi yang dibutuhkan untuk mengevaluasi 
tiga moderator demografi, yaitu: usia, jenis kelamin, dan tahun (lamanya waktu).

4. Hasil/dampak

Suasana hati seseorang dapat memperburuk sebagai akibat dari munculnya rasa penyesalan yang dialami seseorang setelah melakukan prokrastinasi. Dampak yang muncul jika seseorang melakukan prokrastinasi yaitu dapat munculnya kekhawatiran berlebihan terhadap tugasnya. Sedangkan pada kinerja, jika seseorang melakukan prokrastinasi maka konsekuensi yang ditampilkan yaitu kinerja atau prestasi yang rendah.

5. Kontrol diri

Dalam Ghufron (2004) menyatakan ada hubungan yang signifikan antara kontrol diri dan prokrastinasi akademik. Selain itu Ariely \& Wrentonbroch (2002) menyatakan bahwa prokrastinasi adalah salah satu masalah penting dalam pengendalian diri.

6. Kecemasan

Dalam Haycock (2001) disebutkan bahwa ada variabel lain juga yang terkait dengan prokrastinasi adalah kecemasan (anxiety).

\section{Kontrol Diri}

Pengendalian tingkah laku, yaitu melakukan pertimbangan-pertimbangan terlebih dahulu sebelum memutuskan sesuatu untuk bertindak (Averill, 1973). Calhoun dan Acocella (1990) mendefinisikan kontrol diri sebagai pengaturan proses-proses fisik, psikologis, dan perilaku seseorang dengan kata lain serangkaian proses yang membentuk dirinya sendiri.

Dari pernyataan diatas dapat disimpulkan bahwa kontrol diri adalah suatu aktifitas pengendalian tingkah laku, baik fisik maupun psikologis dengan serangkaian proses pertimbangan-pertimbangan terlebih dahulu sebelum bertindak yang akan membentuk dirinya sendiri.

Berdasarkan konsep Averill (1973) terdapat tiga komponen kontrol diri yang meliputi lima aspek, yaitu:

1. Behavioral control

Behavioral control merupakan kesiapan atau tersedianya suatu respon yang dapat secara langsung mempengaruhi atau memodifikasi suatu keadaan yang tidak menyenangkan. Kemampuan mengontrol diri ini diperinci menjadi dua komponen, yaitu mengatur pelaksanaan (regulated administration) dan kemampuan memodifikasi stimulus (stimulus modifiability).

2. Cognitive control

Merupakan kemampuan individu dalam mengolah informasi yang tidak diinginkan dengan cara menginterpretasi, menilai, atau menggabungkan suatu kejadian dalam suatu kerangka kognitif sebagai adaptasi psikologis atau untuk mengurangi tekanan. Aspek ini terdiri atas dua komponen, 
yaitu memperoleh informasi (information gain) dan melakukan penilaian (appraisal).

3. Decisional control

Merupakan kemampuan seseorang untuk memilih hasil atau suatu tindakan berdasarkan pada suatu yang diyakini atau disetujuin. Self control dalam menentukan pilihan akan berfungsi baik dengan adanya suatu kesempatan, kebebasan, atau kemungkinan pada diri individu untuk memilih berbagai kemungkinan tindakan.

\section{Kecemasan}

Nevid, Rathus\&Greene (2005) menyatakan bahwa kecemasan adalah suatu keadaan aprehensi atau keadaaan yang mengeluhkan bahwa sesuatu yang buruk akan segera terjadi, yang diikuti dengan ciri-ciri fisik, kognisi, dan perilaku.

Pendapat lain dikemukakan oleh Sutardjo (2005) yang menyatakan bahwa kecemasan (anxiety) sebagai suatu perasaan yang sifatnya umum, dimana seseorang merasa ketakutan atau kehilangan kepercayaan diri yang tidak jelas asal maupun wujudnya. Cemas adalah suatu keadaan perasaan, dimana individu merasa lemah sehingga tidak berani dan mampu untuk bersikap dan bertindak secara rasional sesuai dengan yang seharusnya.

Dari penjelasan diatas dapat disimpulkan bahwa kecemasan adalah dimana individu merasa lemah sehingga tidak berani untuk bersikap dan bertindak secara rasional sesuai dengan yang seharusnya, mood individu tersebut menjadi negatif dengan ditandai dengan gejala tubuh dari ketegangan fisik, dan ketakutan tentang masa depan yang tidak rasional.

Kecemasan terdiri dari berbagai gejala, Nevid, Rathus\&Greene (2005) menyebutkan ada tiga gejala dari kecemasan, yaitu (1) fisiologis; (2) perilaku; (3) kognitif.

\section{METODE}

Penelitian kuantitatif ini melibatkan 136 sampel (87 laki-laki dan 49 perempuan) dari 204 populasi mahasiswa yang tergabung dalam organisasi pecinta alam UIN Syarif Hidayatullah Jakarta. Teknik pengambilan sampel yang dilakukan adalah proportional stratified sampling.

Alat ukur dalam penelitian ini menggunakan Procrastination Assessment Scale Students yang dikembangkan oleh Solomon\&Rothblum (1984) yang memiliki koefisien reliabilitas 0,80. Alat ukur ini telah diadopsi dan diadaptasi sesuai dengan budaya yang ada pada sampel. Alat ukur kontrol diri dikembangkan oleh peneliti berdasarkan aspek-aspek kontrol diri sesuai dengan konsep Averill (1973). Sedangkan untuk skala kecemasan peneliti menggunakan alat ukur yang berdasarkan atas pernyataan yang terdapat dalam Nevid, Rathus dan Greene (2005) berdasarkan indikator tertentu 
yang terdapat pada ciri-ciri kecemasan, yaitu ciri fisiologis, perilaku, dan kognitif.

Jumlah item pada masing-masing skala adalah 18 item untuk prokrastiansi akademik, 21 item untuk kontrol diri, dan 9 item untuk kecemasan.

Hipotesis dalam penelitian ini adalah kontrol diri, kecemasan, jenis kelamin, dan usia memiliki pengaruh yang signifikan terhadap prokrastinasi akademik mahasiswa yang tergabung dalam organisasi pecinta alam UIN Syarif Hidayatullah Jakarta.

\section{HASIL}

Peneliti menguji hipotesis dengan teknik analisis regresi berganda dengan menggunakan software SPSS 17. Maka akan diperoleh hasil dari tabel $R$ square sebagai berikut:

Tabel 1

$R$ square

\begin{tabular}{|c|c|c|c|c|c|}
\hline Model & $\overline{\mathbf{R}}$ & R Square & $\begin{array}{l}\text { Adjust } \\
\text { Square }\end{array}$ & $\overline{\mathbf{R}}$ & $\begin{array}{l}\text { Std. Error of } \\
\text { the Estimate }\end{array}$ \\
\hline 1 & $.557^{\mathrm{a}}$ & 311 & .279 & & 7.98140 \\
\hline
\end{tabular}

Dari tabel diatas dapat kita lihat bahwa perolehan $R$ square sebesar 0,311 atau $31,1 \%$, artinya proporsi varians dari prokrastinasi akademik yang dijelaskan oleh semua independen variabel adalah sebesar $31,1 \%$, sedangkan $68,9 \%$ sisanya dipengaruhi oleh variabel lain diluar penelitian.

\begin{tabular}{|c|c|c|c|c|c|c|}
\hline & & Ko & $\begin{array}{l}\text { abel } 2 \\
\text { ien Regr } \\
\text { fficients }\end{array}$ & & & \\
\hline & & $\begin{array}{r}\text { Unst } \\
\text { Co }\end{array}$ & $\begin{array}{l}\text { ardized } \\
\text { cients }\end{array}$ & $\begin{array}{c}\text { Standardized } \\
\text { Coefficients }\end{array}$ & & \\
\hline Model & & $\bar{B}$ & $\begin{array}{c}\text { Std. } \\
\text { Error }\end{array}$ & Beta & $\mathbf{T}$ & Sig. \\
\hline 1 & (Constant) & 5.561 & 13.409 & & .415 & .679 \\
\hline & $\begin{array}{l}\text { BEHAVIOR } \\
\text { CONTROL }\end{array}$ & -.531 & .103 & -.459 & -5.183 & .000 \\
\hline & $\begin{array}{l}\text { COGNITIVE } \\
\text { CONTROL }\end{array}$ & -.072 & .073 & -.077 & -.984 & .327 \\
\hline & $\begin{array}{l}\text { DECISIONAL } \\
\text { CONTROL }\end{array}$ & -.026 & .077 & -.028 & -.336 & .737 \\
\hline & KECEMASAN & .204 & .077 & .217 & 2.652 & .009 \\
\hline & USIA & .196 & .143 & .102 & 1.370 & .173 \\
\hline & $\begin{array}{l}\text { JENIS } \\
\text { KELAMIN }\end{array}$ & .029 & .147 & .015 & .200 & .842 \\
\hline
\end{tabular}


Hasil tabel di atas menunjukkan hanya koefisien regresi behavior control dan kecemasan yang signifikan sedangkan sisa lainnya tidak signifikan. Berdasarkan tabel koefisien regresi diatas dapat dijelaskan persamaan regresi berikut:

Prokrastinasi Akademik $=5,561+(-0,531)$ behavior control ${ }^{*}+(-0,072)$ cognitive control $+0,204$ kecemasan $*+0,196$ usia $+0,029$ jenis kelamin.

Berdasarkan uji hipotesis minor kontrol diri (behavior control, cognitive control, decisional control), kecemasan, usia, dan jenis kelamin yang dianalisis secara terpisah dengan masing-masing aspek didalamnya, didapatkan bahwa hanya ada 1 variabel independen dari kontrol diri (behavior control) dan 1 variabel kecemasan yang memiliki pengaruh yang signifikan terhadap prokrastinasi akademik. Kemudian, berdasarkan proporsi varians seluruhnya, prokrastinasi akademik yang dipengaruhi oleh variabel independen kontrol diri (behavior control, cognitive control, dan decisional control), kecemasan, usia, dan jenis kelamin adalah sebesar 31,1\% sedangkan $68,9 \%$ sisanya dipengaruhi oleh variabel lain diluar penelitian.

\section{DISKUSI}

Berdasarkan hasil penelitian dan pengujian hipotesis, didapatkan bahwa ada pengaruh yang signifikan dari variabel kontrol diri (behavior control, cognitive control, decisional control), kecemasan, dan faktor demografis terhadap prokrastinasi akademik mahasiswa yang tergabung dalam organisasi pecinta alam. Hasil penelitian ini mendukung penelitian terdahulu yang dilakukan oleh Kuhnle, Manfred, \& Britta (2011) yang menyatakan bahwa kontrol diri telah terbukti menjadi prediktor yang baik dari prokrastinasi. Individu jelas menunda-nunda karena mereka tidak bisa mengendalikan perilaku mereka dan lebih memilih untuk mengikuti kegiatan jangka pendek yang menyenangkan daripada berpegang pada tujuan mereka. Selain itu, penelitian ini juga mendukung penelitian Ghufron (2004) yang menyatakan semakin rendah kontrol diri, maka semakin tinggi prokrastinasi akademik pada remaja, begitu pula sebaliknya. Secara umum orang yang mempunyai kontrol diri yang tinggi akan menggunakan waktu yang sesuai dan mengarah pada perilaku yang lebih utama, yang bila ia pelajar maka ia akan mengutamakan untuk belajar, sedangkan orang yang mempunyai kontrol diri rendah tidak mampu mengatur dan mengarahkan perilakunya, sehingga akan lebih mementingkan sesuatu yang lebih menyenangkan, dan diasumsikan banyak menunda-nunda.

Variabel selanjutnya adalah kecemasan, penelitian ini mendukung penelitian sebelumnya yang dilakukan oleh Sharma (1997) yang menemukan bahwa kecemasan merupakan salah satu faktor yang berhubungan dengan prokrastinasi. Selain itu, McCown dalam Haycock 
(1998), behavioris percaya bahwa prokrastinasi adalah kebiasaan belajar berkembang dari prefensi manusia untuk kegiatan yang menyenangkan dan imbalan jangka pendek. Sebaliknya, teori psikodinamika melihat prokrastinasi sebagai pemberontakan terhadap orang tua yang terlalu menuntut atau sebagai cara untuk menghindari kecemasan bawah sadar. Hal senada juga diucapkan oleh Senecal dan Koester (1995) yang menemukan bahwa siswa yang menunda-nunda memiliki skor secara signifikan lebih tinggi daripada siswa lain pada variabel kecemasan.

Variabel demografi yang konsisten diteliti dalam studi prokrastinasi adalah usia. Steel (2007) menyatakan bahwa faktor usia juga menjadi faktor untuk mengembangkan informasi tentang subjek penelitian. Hal ini juga diperkuat oleh penelitian Haycock (1998) yang juga memasukkan faktor usia juga menjadi faktor yang mempengaruhi prokrastinasi. Tetapi dalam penelitian ini, peneliti mendapatkan bahwa usia secara tidak signifikan mempengaruhi prokrastinasi akademik mahasiswa. Usia yang diteliti dalam penelitian adalah 18-27 tahun, dan dibagi menjadi dua rentangan yaitu, 1820 tahun dan 21-27 tahun. Bila dilihat dari kedua rentang tersebut maka menurut Erikson usia tersebut adalah usia dimana seseorang berada dalam jenjang remaja dan dewasa awal, yang dalam hal ini mempunyai tugastugas perkembangan. Hurlock (1980) menyebutkan beberapa alasan yang menyebabkan perubahan nilai dalam rentang usia ini, diantara yang sangat umum adalah banyak orang pada usia ini menyadari bahwa sikap yang seharusnya tidak dilakukan harus diganti dengan tingkah laku yang dapat diterima, menyadari bahwa banyak kelompok sosial berpedoman kepada nilai-nilai yang konservatif, yaitu mereka yang terutama memikirkan kepuasan diri sendiri lambat laun akan mengembangkan kesadaran dan keterlibatan sosial. Dalam penelitian ini diharapkan mahasiswa dengan rentang usia ini dapat lebih dewasa dalam menentukan mana yang seharusnya mereka selesaikan tepat waktu dan yang hanya menjadi keinginan refreshing, agar dapat menyelesaikan tanggung jawab mereka sebagai mahasiswa dengan baik.

Variabel demografis lainnya yang ikut diteliti adalah variable jenis kelamin. Steel (2007) menyatakan bahwa pengaruh jenis kelamin dalam penelitian terhadap prokrastinasi sulit untuk diprediksi. Beberapa penelitian menunjukkan tidak ada perbedaan jenis kelamin yang signifikan dalam terjadinya prokrastinasi, sedangkan penelitian lain menunjukkan bahwa wanita berada pada resiko yang lebih besar daripada laki-laki. Selain itu, wanita mungkin mengalami tingkat kecemasan yang lebih besar terkait dengan prokrastinasi (Haycock, 1998). Penelitian ini juga mendukung penelitian sebelumnya yang juga menyatakan bahwa variabel jenis kelamin tidak secara signifikan mempengaruhi prokrastinasi akademik.

Untuk penelitian selanjutnya peneliti menyarankan:

1. Variasi dari enam variabel independen yang ada dalam penelitian ini memberikan sumbangan sebesar $31,1 \%$ sedangkan $68,9 \%$ sisanya 
dipengaruhi oleh variabel lain diluar penelitian ini. Oleh karena itu, disarankan untuk penelitian-penelitian selanjutnya agar meneliti mengenai variabel-variabel lain yang mempengaruhi prokrastinasi akademik seperti self-esteem, fear of failure, self efficacy, tipe kepribadian, dukungan sosial, dan pola asuh orang tua sehingga mampu mendapatkan hasil yang lebih baik karena data yang ada lebih akurat.

2. Untuk penelitian selanjutnya diharapkan menggunakan sampel yang lebih besar, tidak hanya di UIN Syarif Hidayatullah Jakarta, namun juga universitas atau organisasi lain yang berbeda untuk melihat tingkat perbedaan prokrastinasi akademik yang lebih komplek.

\section{DAFTAR PUSTAKA}

Averil, James. R. (1973). Personal Control Over Aversive Stimuli and Its Relationship to Stress. Psychological Bulletin. Vol. 80, 286-303.

Barlow. David H., Durand. V Mark. (2002). Abnormal Psychology: An Intergrative Approach. Canada: Thomshon Learning academic Resource Center

Burka. Jane B. \& Yuen. Lenore M. (1983). Procrastination: Why you do it, what to do about it now. USA: Da Capo Press.

Colhaoun, Jams. F, \& Acocella, Joan. Ross. (1990) Psikologi tentang Penyesuaian dan Hubungan Kemanusiaan. Semarang: IKIP Semarang Press.

Chu, Angela. Sin Chun. \& Choi, Jin. Nam. (2005). Rethingking Procrastination: Positive Effects of "Active" Procrastination Behavior on Attitudes and Performance. The journal of social Psycholog. 145 (3), $245-264$

Froese, Arnold D., Nisly, Sheryl J.. \& May, Roxanna M. (1984). The Effects of Task Interest and Difficulty on Procrastination. Journal Transactions of the Kansas academy of science. 87(3-4), 119-128.

Ghufron, M. Nur. (2004). Hubungan kontrol diri dan persepsi remaja terhadap penerapan disiplin orang tua dengan prokrastinasi akademik. Tabularasa, volume 2, nomor 1 .

Ghufron, M. Nur., \& S. Risnawita Rini. (2010). Teori- teori psikologi. Jogjakarta: Ar-Ruzz Media Group.

Haycock, Laura. A., McCarthy, Patricia., \& Skay. Carol. L. (1998). Procrastination in College Student: The Role of Self-Efficacy and Anxiety. Journal of Counseling \& Development. Vol. 76.

Hurlock, Elizabeth. B. (1980). Psikologi Perkembangan suatu pendekatan sepanjang rentang kehidupan. Jakarta: Erlangga.

Kazdin. Alan E. (1975). Bealavior Modification in Applied Setting. Ontario. USA: The Dorsey Press 
Kuhnle. Claudia... Hofer, Manfred \& Kilian. Britta (2011). The Relationship of Self Control. Procrastination. Motivational Interference and Regret with School Grades.

Nevid, Jefrfrey. S.. Rathus. Spencer. A \& Greene. Beverly. (2005). Psikologi Abnormal. Jakarta: Erlangga

O'Donoghue \& Rabin. Matthew. (2001), Choice and procrastination. The quarterly journal of economics. 116(1), 121-160.

Pedhazur. Elazar J. (1982). Multiple regression in behavior research: explanation and prediction. New York.

Santrock. John. W. (2007). Remaja. Jakarta: Erlangga.

Senecal, Caroline.. \& Koestner. Richard. (1995). Self Regulation and Academic Procrastination. The journal of Sosial Psychology. 135(5). 607619.

Sevilla. Consuelo G.. dkk. (1993). Pengantar Metode Penelitian. Jakarta: UI Press.

Sharma. Pal Madan. (1997). Task procrastination and its determinants. Journal of industrial relationship. 33(1), 17-33.

Solomon. Laura. J.. \& Rothblum, Esther, D. (1984). Academic Procrastinastion: Frequency and Cognitive-Behavior Correlates. Journal of counseling psychology.Vol.31, No. 4. 503-509. 